\title{
Cochlear Implantation, Synaptic Plasticity and Auditory Function
}

\author{
Jahn N. O'Neil ${ }^{1}$ and David K. Ryugo ${ }^{1,2}$ \\ ${ }^{1} J o h n s$ Hopkins University, Dept. of Otolarygology, Head and Neck Surgery, \\ Center for Hearing and Balance, Baltimore, MD \\ ${ }^{2}$ Garvan Institute of Medical Research, Hearing Research, Sydney, NSW \\ ${ }^{1}$ USA \\ ${ }^{2} A U$
}

\section{Introduction}

The ability to hear, our perception of sound, is fundamental to how we perceive our external environment and interact with others using spoken language. Sound also plays a critical role in the normal development of the auditory system. In this review, we will discuss sound, hearing, and the role of hearing in brain development. We will examine the effect of deafness and the impact of cochlear implants on neuronal plasticity and auditory function.

It is speculated that hearing evolved as a distance sense so that organisms could detect potential dangers that were not visible, such as during the dark of night or where grass or forests were too dense (Jerison, 1973). All animals have the ability to sense mechanical perturbations in the air, and in vertebrates, the inner ear is a highly developed structure that solves this problem. This sense organ consists of specialized cellular structures that transduce (or convert) sound stimuli into neural signals.

Sound is created by vibrations within a plastic medium (air, water, gas etc.) caused by the movement of molecules. The oscillations of these sound waves can be described by their rate, which is defined in cycles per second, also known as frequency. The sensation of pitch is positively correlated to the frequency of sound. The pressure (or intensity) of these vibrations is perceived as loudness. Sound in air is captured by the auricle, the external portion of the ear, and funneled through the external auditory canal to the tympanic membrane, also known as the eardrum. The tympanic membrane is mechanically coupled to the middle ear ossicles (malleus, incus and stapes) where the vibrations are amplified and delivered to the cochlea. The vibrations in air become vibrations in fluid and are transmitted to the sensory hair cells of the organ of Corti. This mechanical signal is converted to neural signals and relayed to the brain by the auditory nerve. The brain receives and interprets these signals and the result is what we perceive as hearing.

In humans, the range of hearing that is audible contains frequencies between approximately 20 to 20,000 Hz. Hearing range is variable between individuals as well as species (Figure 1). Mammals in particular have developed high frequency hearing and have the largest 
frequency range among vertebrates. The ear is the structural organ that detects sounds, however, the brain is the organ that perceives sound through the firing of nerve cell impulses. This neural activity is important for the normal construction and maintenance of the auditory structure and function. The brain combines auditory input received from both ears to determine the level, direction and distance of the sound. The inability of the brain to perceive auditory information from one or both ears is termed hearing loss. Hearing loss is the most common sensory loss, affecting millions worldwide. In the U.S., the National Institute of Deafness and Other Communications Disorders, (NIDCD) has determined that 2-3 out of 1,000 newborns, and 36 million adults are affected by hearing loss (http://www.nidcd.nih.gov/health/statistics/Pages/quick.aspx). Hearing loss or deafness can be defined as congenital or acquired. Congenital hearing loss occurs at birth, whereas acquired deafness occurs after birth. The type of hearing loss is classified as sensorineural, conductive or mixed. Sensorineural hearing loss is defined as being caused by an abnormality in the inner ear, cranial nerve VIII (auditory nerve), or the central processing auditory centers of the brain. Conductive hearing loss occurs when sound is not being conducted efficiently throughout the ear canal, eardrum and the middle ear.

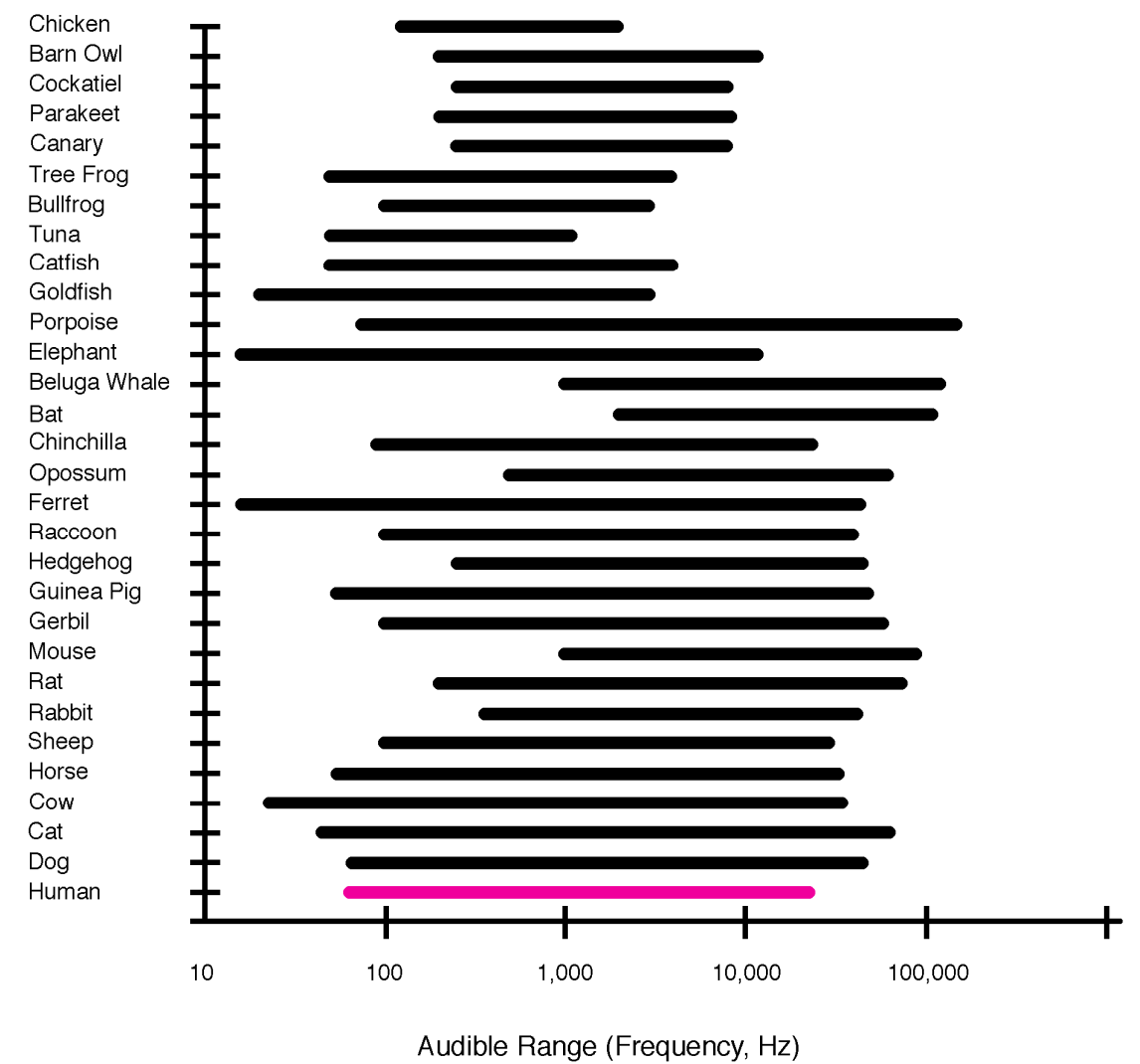

Fig. 1. Hearing Range * approximate values, not drawn to scale (adapted from Fay, R.R. (1988). Hearing in vertebrates: a psychophysics databook, Hill-Fay Associates, Winnetka, IL). 
For many individuals affected by hearing loss, depending on the severity of hearing impairment, listening needs, and lifestyle, several options are available. Current treatment of sensorineural hearing loss is available via acoustic hearing aids, implantable middle ear hearing devices, and cochlear implants. Hearing aids are widely used to amplify and modulate sound enabling an individual with damaged hearing to communicate and participate more fully in daily activities. Cochlear implants, however, provide a sense of sound to individuals profoundly deaf or severely hard of hearing. Implants work to bypass the sensory hair cells within the organ of Corti. Conversely, hearing aids amplify sound. Cochlear implants do not restore normal hearing but rather provides the individual with a useful representation of sounds in the environment. Other acoustic aids such as middle ear implants work to remedy ossicular dysfunction and auditory brainstem implants work by bypassing the auditory nerve and is implanted directly into the midbrain. The biggest and still outstanding problem with listening aid devices is their inability to function optimally in the presence of background noise.

The improved quality of cochlear implants over the last several decades have restored hearing to more than 200,000 deaf patients worldwide, in the US alone, over 42,000 adults and 28,000 kids (http://www.nidcd.nih.gov/health/hearing/pages/coch.aspx.) Cochlear implants have become the most successful neural prostheses to date. Cochlear implants have been found to be most beneficial to post-lingually deafened adults and young children (Waltzman \& Roland, 2005; Niparko et al., 2009). The use of auditory training has been found to induce post-implantation synaptic plasticity and to enhance post-implantation performance. Auditory function with cochlear implantation has achieved enormous success in the past several years. The robust outcomes and satisfaction of cochlear implant patients have contributed to the widespread acceptance of implant use.

\section{Historical origin of cochlear implants}

Cochlear implants work by directly stimulating the auditory nerve. It requires both a surgical approach and significant post-surgical training. The earliest example of electrical stimulation to the auditory system was by an Italian physicist, Alessandro Volta in 1790. Volta is famous for discovering the first practical method of generating electricity, the electrolytic cell. By placing the ends of metal rods in his ears connected to an electrical supply (approx. $50 \mathrm{~V}$ ), he discovered that the initial "boom in the head" was followed by a resultant electronic sound similar to "a thick boiling soup" - what we know now to be electronic static. Over the next several decades, it was surmised that since sound is more of an alternating sinusoidal signal, stimulation via direct current (DC) would probably not produce an adequate hearing sensation. In the early 19th century, the Frenchman Duchenne used an alternating current to stimulate hearing. His observation was described "as a sound similar to an insect trapped between a glass pane and a curtain."

Wever \& Bray, (1930) went on to discover that an electrical response recorded near the auditory nerve of a cat was similar in frequency and amplitude to the stimulating sound. Gersuni \& Volokhov, (1936) are credited for observing the effects of an alternating electrical stimulus on hearing. Another important discovery made by these investigators was that hearing could persist even after surgical removal of the tympanic membrane and middle ossicles, and thus hypothesized that the cochlea was the site of stimulation. Stevens \& Jones, (1939), observed that several mechanisms produced hearing when the cochlea was 
stimulated electrically. Direct stimulation of the auditory nerve in a human was performed by Lundberg in 1950 and resulted in the patient hearing noise. In 1957, French-Algerian surgeons Andre Djourno and Charles Eyries directly stimulated exposed acoustic nerves and reported the patients' experience when current was applied (Djourno et al., 1957). It became distinctly apparent to researchers during the 1940's and 1950's that if precise hearing sensations were to be produced it would be more beneficial for current to be applied locally rather than widespread.

In 1961, William House developed a device to stimulate auditory function based in part on notes made by Djourno and colleagues. Together with Jack Urban, an engineer, he developed a single channel electrode implant device to assist with lip reading. Three deaf patients received this implant, with all reporting some benefit. Doyle et al., (1964), is credited for designing a four-electrode implant to try to limit the spread of the electrical current within the cochlea. Results obtained from a singular patient were only satisfactory, the most significant finding being the patients' new ability to repeat phrases. Simons, (1966) went on to perform a more extensive study by placement of electrodes throughout the promontory and vestibule areas and into the modiolar section of the auditory nerve. This approach allowed for stimulation of auditory fibers representing different frequencies. Results from testing showed the patient was able to discern the length of the stimulus duration and tonality could be achieved.

Cochlear implantation was tested and refined by use of scala tympani implantation of electrode arrays driven by an implantable receiver-stimulator by House, (1976) and Michelson, (1971). The House 3M single channel cochlear implant was the first to be commercially available in the US receiving FDA approval in 1984. Several hundred of these were implanted in patients beginning in 1972 and throughout the mid 1980's.

Meanwhile, outside the US, progress was being made by Graeme Clark in Australia. Professor Graeme Clark and colleagues developed a multi-channel cochlea implant, which enhanced the spectral perception and speech recognition capabilities in adult patients. This device was implanted in Rod Saunders in 1978, the first multi-channel cochlear implant recipient in the world. By the late eighties this implant marketed under the name "Nucleus Multi-channel Cochlear Implant" by Cochlear Pty Ltd. became the most widely used. This device received FDA approval in 1984 for use in adults, however by 1990 the age was reduced to 2, by 1998 to age 18 months, and by 2002 age 12 months. In some cases special approval have been obtained from the FDA for cochlear implantation of babies as young as 6 months of age (Eisen, 2009).

Today, due to advancement of technical and electronic development over the last few years, the size of the external components has been decreased in all commercially available cochlear implants. Companies such as Advanced Bionics and Neurelec provide only cochlear implants. Med El and Cochlear Corp., in addition to cochlear implants offer the middle ear implant system and Baha ${ }^{\circledR}$ bone conduction system respectively. As recently as last year, 2010, the FDA approved the Esteem ${ }^{\circledR}$ Totally Implantable Hearing System by Envoy Medical --intended to alleviate moderate to severe hearing loss in adults. The Esteem system, functions by sensing vibrations from the eardrum and the middle ear and converts these mechanical vibrations into electrical signals thereby replicating the ossicular chain and providing addition gain. 


\section{Animal models of deafness}

Many different models of congenital deafness have been studied and include, cochlear ablation, acoustic trauma, ototoxic drugs, and hereditary deafness. The power of experimental animal models is that they enable researchers to study the effects of deafness in the auditory system and to infer mechanisms of pathophysiology in highly invasive preparations that would not be possible in human subjects. The consequences of congenital versus acquired deafness often reveal the importance of features involved in development. Neural activity is critical for normal construction and maintenance of auditory structure and function (Parks et al., 2004; Shepherd et al., 2006) with its lack having important implications on the auditory pathway. Neural activity influences the refinement of the genetic blueprint for circuitry including axonal distribution and synapse formation within the auditory system (Leake et al., 2006; Baker et al., 2010). In the absence of auditory stimulation, a series of pathological and atrophic changes is introduced that include more widespread distributions of axonal projections (Leake \& Hradek, 1988), abnormal projections (Nordeen et al., 1983) delayed maturation (Kandler, 2004), and language impairments (Robbins, 2006).

The developing animal highlights the importance of auditory stimulation. Lack of auditory stimulation early in the postnatal period produces severe abnormalities in the auditory pathways, whereas, in mature animals with previous auditory experience, these effects are diminished (Rubel \& Parks, 1988). These observations have been associated with the age related benefits of cochlear implantation in congenitally deaf humans (Waltzman et al., 1991; Gantz et al., 1994) because younger children typically gain more benefit from a cochlear implantation than older children. Data imply that deafness causes change in the central nervous system that, if not corrected, interferes with implant effectiveness.

For the purpose of this chapter we will focus primarily on the congenitally deaf white cat model of deafness. The congenitally deaf white cat model manifests a type of cochleosaccular degeneration that causes sensorineural hearing loss, mimicking the Scheibe deformity in humans (Scheibe, 1882; Suga \& Hattler, 1970). Deafness in these animals is manifest by a collapse of Reissner's membrane, which obliterates the scala media and the organ of Corti (Figure 2).

It is not possible to conclude that deafness is solely due to the collapse of Reissner's membrane. First, these kittens are all born with normal looking cochlear morphology (Baker et al., 2010). It is only after the end of the first postnatal week that the pathology begins to emerge. The stria vascularis is pathologically thin, and this abnormality accompanies an irregular lengthening of Reissner's membrane that causes it to undulate. In addition, there is shrinkage of the tectorial membrane and it begins to curl upon itself and roll against the spiral ligament. This lengthening of Reissner's membrane proceeds rather rapidly such that it collapses by the end of the second postnatal week. By this time, the tectorial membrane is tightly curled against the spiral ligament. At the start of the third postnatal week of life, those kittens that are destined to become deaf exhibit a completely pathologic inner ear with no cochlear duct and no organ of Corti. Hair cell receptors are completely absent.

\section{Synaptic morphology}

Surprisingly, there are abnormalities in auditory nerve synapses in the cochlear nucleus that are evident at birth. The surprise is because it occurs well before the onset of hearing, and 
the idea had been that the effects of deafness wouldn't appear until after the normal onset of hearing. The delayed effect was presumed to occur because a lack of sound-evoked activity was hypothesized to underlie the abnormal synapses. The occurrence of abnormal synapses prior to the lack of activity implies that the system knows that it is deaf before there is evidence that the animal can hear or not.

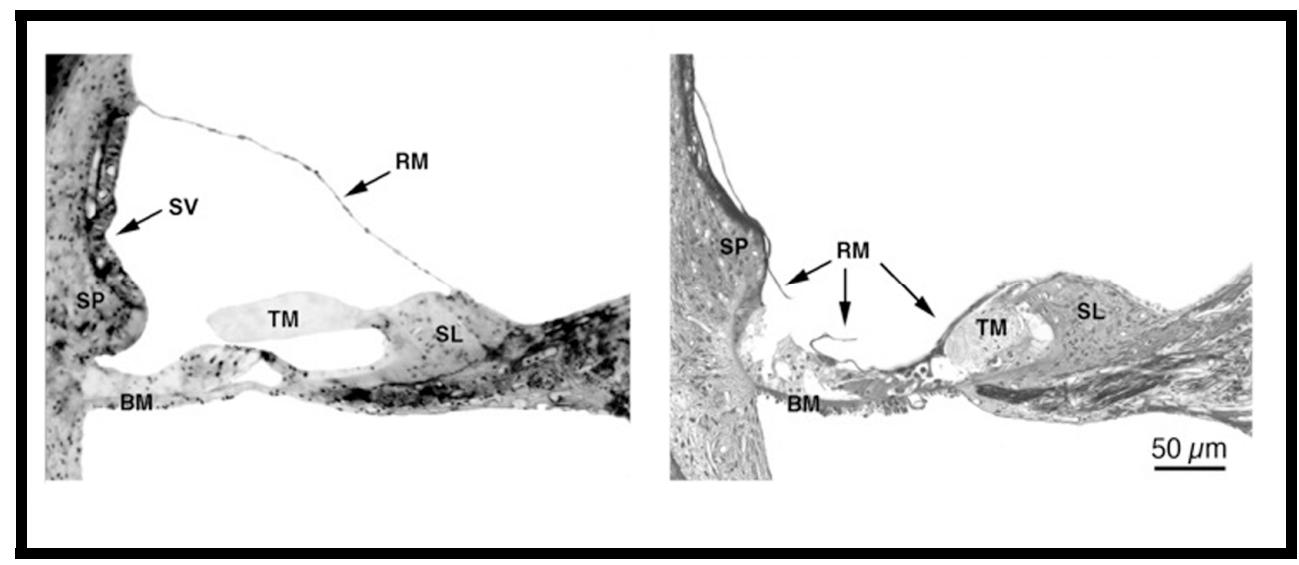

Fig. 2. Light micrographs of mid-modioloar sections showing the organ of Corti from a normal hearing (left) and deaf cat (right). $\mathrm{RM}=$ Reissners membrane, $\mathrm{SP}=$ spiral prominence, $\mathrm{BM}=$ basilar membrane, $\mathrm{TM}=$ tectorial membrane, $\mathrm{SL}=$ spiral limbus, $\mathrm{SV}=\mathrm{Stria}$ vascularis.

Synapses are definable not only by presynaptic characteristics at the release site such as synaptic vesicle size and shape, transmitter chemicals, neuromodulators, and transporter molecules but also by the postsynaptic composition of transmitter receptor subunits, shape and curvature of the postsynaptic density (PSD), ion channels, and associated second messenger and retrograde signaling systems. Moreover, there must also be consideration of size and distribution of the terminal, target compartment (e.g., cell body, dendritic shaft, spine), and location of the cell bodies that give rise to the projection. Proper transmission of acoustic signals from neuron to neuron depends in large part on the precise spatial arrangement of these factors at the release site. The corollary to this notion is that abnormalities of synaptic structure will impair signal transmission, thereby corrupting the neural representation of the acoustic stimulus.

For the processing of sound, neural activity in the central nervous system must be tightly coupled in time to acoustic events. Sound, perhaps more than any other sensory stimuli, conveys meaning by the time-varying nature of frequency and level (or loudness). By virtue of the time-dependence of sound for information significance, neural activity pertaining to sound must be synchronized to time-dependent variables of the physical stimulus. Different sounds are revealed by distinctive characteristics in their time-varying features. It is accepted that different features of the physical components of sound are parsed and sent along separate and distinct pathways. Eventually, the information conveyed down the various circuits must reconvene with precise timing to produce a conscious percept of the stimulus. It is for these reasons that timing is so important to the auditory system. As a corollary, aberrations in these pathways will corrupt processing and disturb how sound is perceived. 
The hair cell receptors within the cochlea transduce sound energy into neural signals in auditory nerve fibers that are conveyed to the cochlear nucleus (Kiang et al., 1965). The cochlear nucleus receives all incoming auditory information and gives rise to the ascending auditory pathways. The relatively homogeneous responses of incoming auditory nerve fibers are transformed into a variety of different response patterns by the different classes of resident neurons in the cochlear nucleus. These signals are in turn transmitted to higher centers by the ascending pathways. The spectrum of the responses depends not only upon the synaptic organization of the auditory nerve but also on intrinsic neurons and descending inputs; the types and distribution of receptors, ion channels, and G proteins; and second messengers. These features form the signaling capabilities for each cell class. In order to understand how sound is processed, there is a need to study identified cell populations, to analyze their synaptic connections, and to reveal features of their signal processing capabilities.

Auditory nerve fibers are the major source of excitation to cells of the ventral cochlear nucleus (Koerber et al., 1966). In the anteroventral cochlear nucleus (AVCN), myelinated auditory nerve fibers give rise to large, axosomatic synaptic endings known as endbulbs of Held (Held, 1893; Lorente de Nó, 1981). Endbulbs have a calyx-like appearance where the end of the fiber is marked by the emergence of several thick, gnarled branches that divide repeatedly to form an elaborate arborization of en passant and terminal swellings to embrace

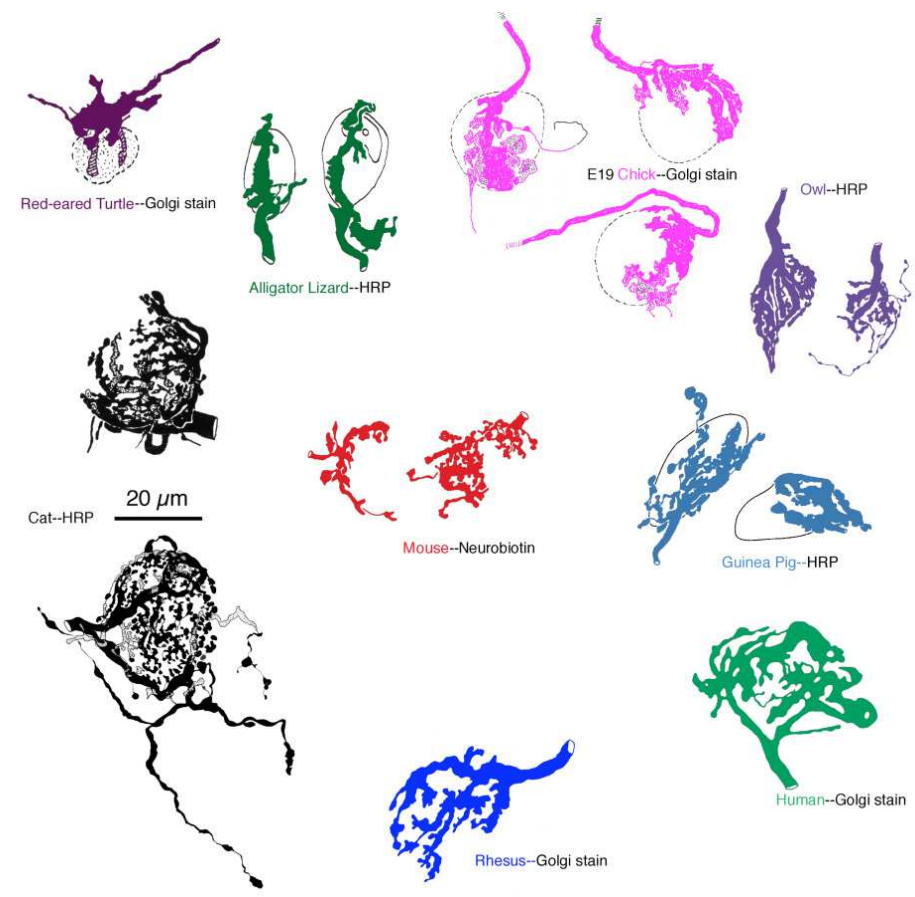

Fig. 3. Photomicrographs of the Endbulb of Held in different vertebrate species showing the evolutionary conservation of this synapse. (Adapted from Ryugo, D.K. \& Parks, T.N. (2003). Brain Res Bull, Vol. 60, No. 5-6, pp. 435-456). 
the postsynaptic spherical bushy cell (SBC, Ryugo \& Fekete, 1982). These endbulbs are among the largest synaptic endings in the brain (Lenn \& Reese, 1966), and one-to-three endbulbs selectively contact a single SBC (Ryugo \& Sento, 1991; Nicol \& Walmsley, 2002). They contain up to 2,000 release sites (Ryugo et al., 1996) and transmit activity with highfidelity to the postsynaptic SBC (Babalian et al., 2003). The size and evolutionary conservation of endbulbs among vertebrates emphasize its importance in enabling spike activity to be yoked in time to acoustic events (see Figure 3).

\subsection{Normal hearing animals}

During postnatal development, the endbulb of Held begins with the formation of a solid, spoon-shaped growth cone and culminates in a highly branched axosomatic arborization. Each endbulb can form hundreds of synapses onto the postsynaptic SBC (Ryugo et al., 1996). This feature in particular suggests a highly secure synaptic interface to maintain the temporal fidelity of all incoming signals to the SBC (Manis \& Marx, 1991). The structure of this giant synaptic terminal has been extensively studied to learn about synapse formation, its target specificity, and its reaction to deafness (Limb \& Ryugo, 2000; Ryugo et al., 1997, 1998; Oleskevich et al., 2004, see Figure 4).

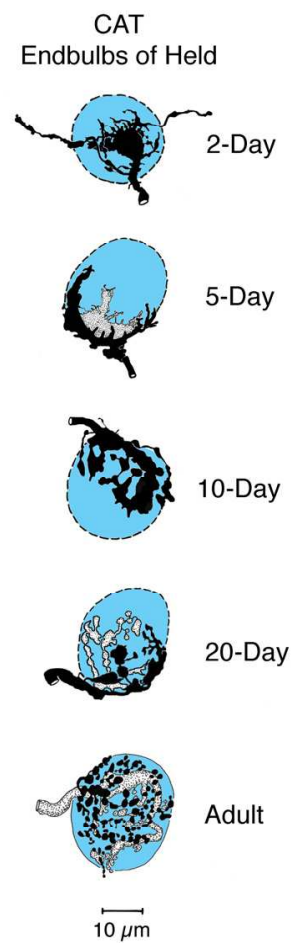

Fig. 4. Development of the endbulb of Held in a normal hearing cat from birth to adulthood. (Adapted from from Ryugo, D.K. \& Spirou, G.A. (2009). Auditory System: Giant Synaptic Terminals, Endbulbs and Calyces. In: New Encyclopedia of Neuroscience, Vol. 1, Squire, L.R. (Ed.), pp. 759-770, Academic Press, Oxford). 
In normal hearing cats, the endbulb arborization onto the SBC have been shown to vary systematically with respect to the average level of spike discharges received from auditory nerve fibers having low or high levels of activity. Endbulbs from fibers having high levels of activity (e.g., high (>18 s/s) spontaneous discharge rates and low thresholds for evoked responses) exhibit modest levels of branching with relatively large en passant and terminal swellings. In contrast, endbulbs from fibers having relatively low levels of activity (e.g., low $(<18 \mathrm{~s} / \mathrm{s})$ spontaneous discharge rates and high thresholds for evoked responses) exhibit highly elaborate branching with relatively small en passant and terminal swellings (Figure 5). The differences in branching complexity were confirmed by statistically significant differences in fractal values. Moreover, the larger swellings on the highly active endbulbs resembled the swollen endings of overactive terminals where it was speculated that the swelling was caused by the fusion of synaptic vesicles (Burwen \& Satir, 1977). Using electron microscopy to study synaptic ultrastructure, endbulbs receiving relatively low levels of spike discharges were associated with larger PSDs, whereas those exhibiting high rates of spike discharges exhibited smaller PSDs (Ryugo et al., 1996). These data are consistent with observations from rats exposed to repetitive tones or silence; stimulated animals exhibited endbulbs with smaller PSDs compared to those of animals exposed to silence (Rees et al., 1985). The synapse structure of endbulbs is clearly plastic and subject to activity-related change.

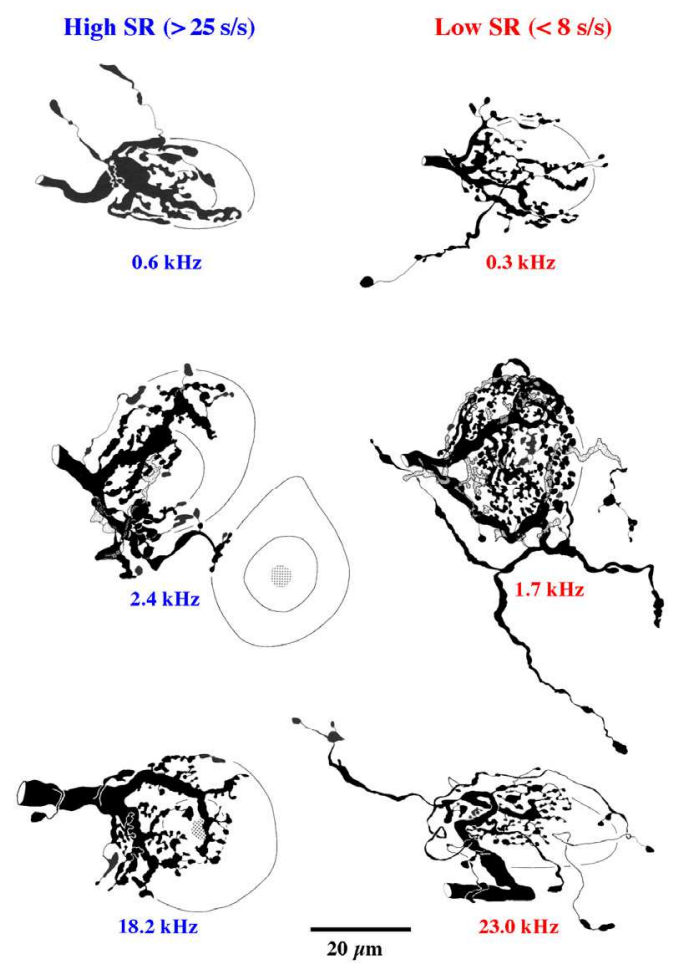

Fig. 5. Endbulbs of Held activity related changes. (Adapted from Sento, S. \& Ryugo, D.K. (1989). Endbulbs of Held and spherical bushy cells in cats: Morphological correlates with physiological properties. J Comp Neuro, Vol. 280, No. 4, pp. 553-562). 


\subsection{Congenitally deaf animals}

The endbulb synapse has been studied in congenitally deaf white cats to infer the extent to which sound influences its growth (Ryugo et al., 1997, 1998). Due to the elaborate form of the endbulb, changes in morphology should be evident and quantifiable. Moreover, given that variations in endbulb morphology were already apparent in normal hearing cats where differences could be attributed to disparities in spike discharge rates, it was predicted that in the extreme case of congenital deafness, there should be definable and obvious abnormalities.

Single unit recordings in the auditory nerve of congenitally deaf white cats revealed several important features. First, in completely deaf cats, there was little spontaneous activity and no evoked activity. Second, in hard of hearing cats (thresholds $>60 \mathrm{~dB}$ ), there was spontaneous activity, but elevated in distribution. Spontaneous activity in general was similar to that of normal hearing cats, but the upper range of spontaneous activity was extended (>150 s/s). In some auditory nerve fibers, spontaneous discharges exceeded $180 \mathrm{~s} / \mathrm{s}$. These data on activity were consistent with inner ear histology: deaf animals exhibited no organ of Corti, whereas hard of hearing animals exhibited a full complement of hair cells but showed signs of hydrops with an outward bulging Reissner's membrane (Ryugo et al., 1998).

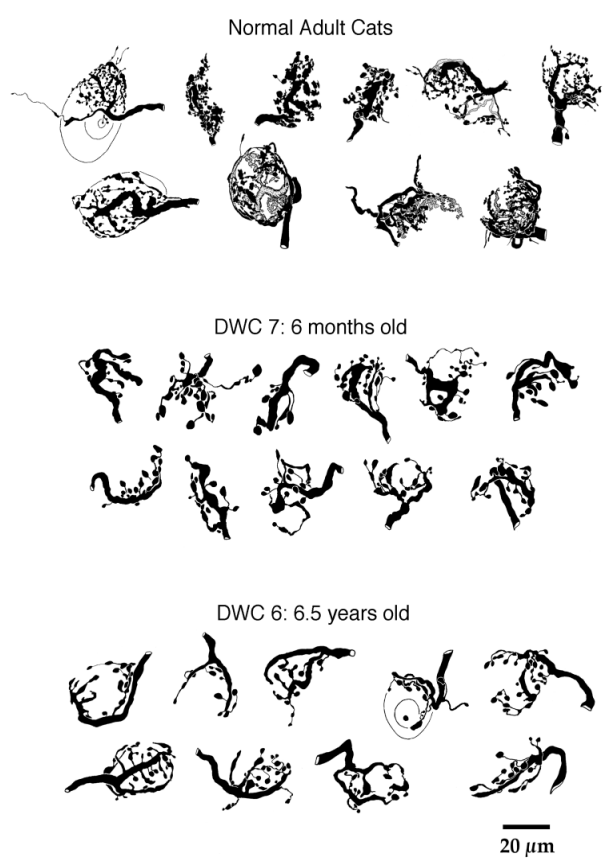

Fig. 6. Three-dimentional reconstruction of HRP-labeled endbulbs. Note the branching complexity is correlated to hearing status. (Adapted from Ryugo, D.K.; Pongstaporn, T.; Huchton, D.M. \& Niparko, J.K. (1997). Ultrastructural analysis of primary endings in deaf white cats: Morphologic Alterations in Endbulbs of Held. J Comp Neurol, Vol. 385, No. 2, pp. 230-244 and Ryugo, D.K.; Rosenbaum, B.T.; Kim, P.J.; Niparko, J.K. \& Saada, A.A. (1998). Single unit recordings in the auditory nerve of congenitally deaf white cats: Morphological correlates in the cochlea and cochlear nucleus. J Comp Neurol, Vol. 397, No. 4, pp. 532-548). 
The most obvious structural correlate in the cochlear nucleus was that the endbulbs contacted significantly smaller postsynaptic SBCs (Saada et al., 1996; O'Neil et al., 2010; Ryugo et al., 2010). Second, the degree of endbulb arborization was graded in arborization complexity with respect to hearing threshold. In completely deaf cats, the extent and complexity of endbulb branching were less with significantly fewer swellings (Ryugo et al., 1997, 1998). These features were quantified by fractal analysis. Cats with elevated thresholds exhibited statistically different fractal values from completely deaf cats and normal hearing cats. Normal hearing cats displayed the most elaborate and complex endbulb arborizations (see Figure 6).

When these endbulbs were examined at greater resolution with an electron microscope, additional features are affected by hearing loss (Ryugo et al., 1997, 1998). In normal hearing cats, endbulbs give rise to numerous punctate, dome-shaped PSDs. Surrounding the PSD were accumulations of round, clear synaptic vesicles (Figure 7). In contrast, endbulbs of congenitally deaf white cats exhibited a flattening and hypertrophy of the PSDs (see Figure 8). Moreover, there was a striking increase in synaptic vesicle density near the release site (Baker et al., 2010). The endbulb synapses from cats that were not deaf but suffering from hearing loss exhibited features that were intermediate between those of normal hearing and completely deaf cats (Ryugo et al., 1998). That is, the PSDs were intermediate in size and curvature.
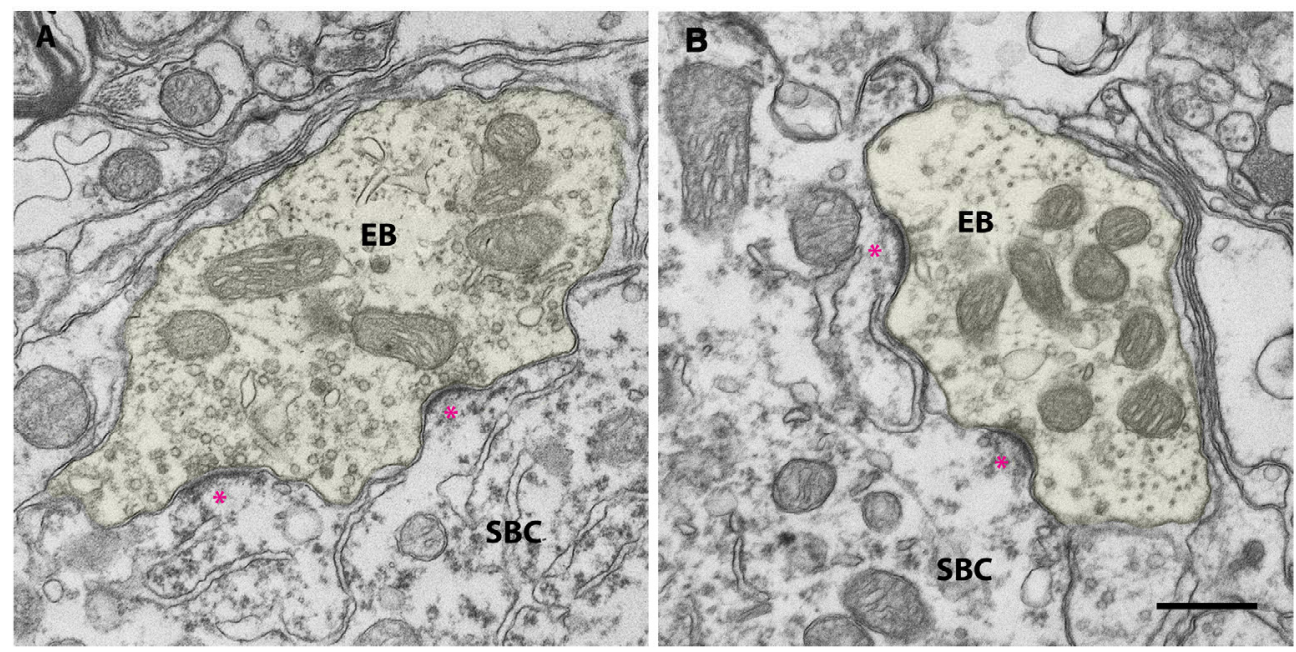

Fig. 7. Electron micrographs showing endbulbs of Held (EB) in normal cats. Note the typical dome-shaped appearance of PSDs marked with asterisk. Scale bar $=0.5 \mu \mathrm{m}$. (Adapted from O'Neil, J.N.; Limb, C.J.; Baker, C.A. \& Ryugo, D.K. (2010). Bilateral effects of unilateral cochlear implantation in congenitally deaf cats. J Comp Neuro, Vol. 518, No. 12, pp. 2382-2404).

Deafness and hearing loss caused abnormalities in endbulb branching, soma size, and synapse morphology that were statistically different between cohorts (Ryugo et al., 1998). Abnormalities in synaptic transmission do not just occur with complete deafness. There has been transmission abnormalities reported in DBA/2J mice with hearing loss (Wang \& Manis, 2006). These changes reveal that auditory synapses are highly sensitive to the quantity and quality of simulation. The presence of transmission irregularities from the 
presynaptic endbulb to the postsynaptic SBC could introduce jitter or perhaps even transmission failure. Such interruptions would diminish the precise processing of timing information. The implication is that even hearing loss will produce difficulties beyond elevated thresholds.

\subsection{Chemical (ototoxic), and genetic deafening}

The question could be asked whether the synaptic changes observed in the deaf cats are due to loss of neural activity in the auditory nerve, or whether they are part of the genetic syndrome and unrelated to spike activity. Several arguments can be presented to counter this concern. First, ototoxic deafening produces a similar flattening and hypertrophy of the PSD (Ryugo et al., 2010). Second, in Shaker-2 mice whose deafness is caused by a mutation of the myosin 15 gene that leads to loss of hair cells, changes in endbulb arborization (Limb \& Ryugo, 2000) and synaptic morphology (Lee et al., 2003) resemble those of the congenitally deaf white cat. Third, similar pathologic changes in endbulb morphology have been observed in the congenitally deaf guinea pig (Gulley et al., 1978). Because non-feline animals with deafness caused by independent means and cats of normal genetics but deafened by drugs all show these same synaptic anomalies, we can attribute the synaptic pathology to the lack of auditory nerve activity caused by deafness.
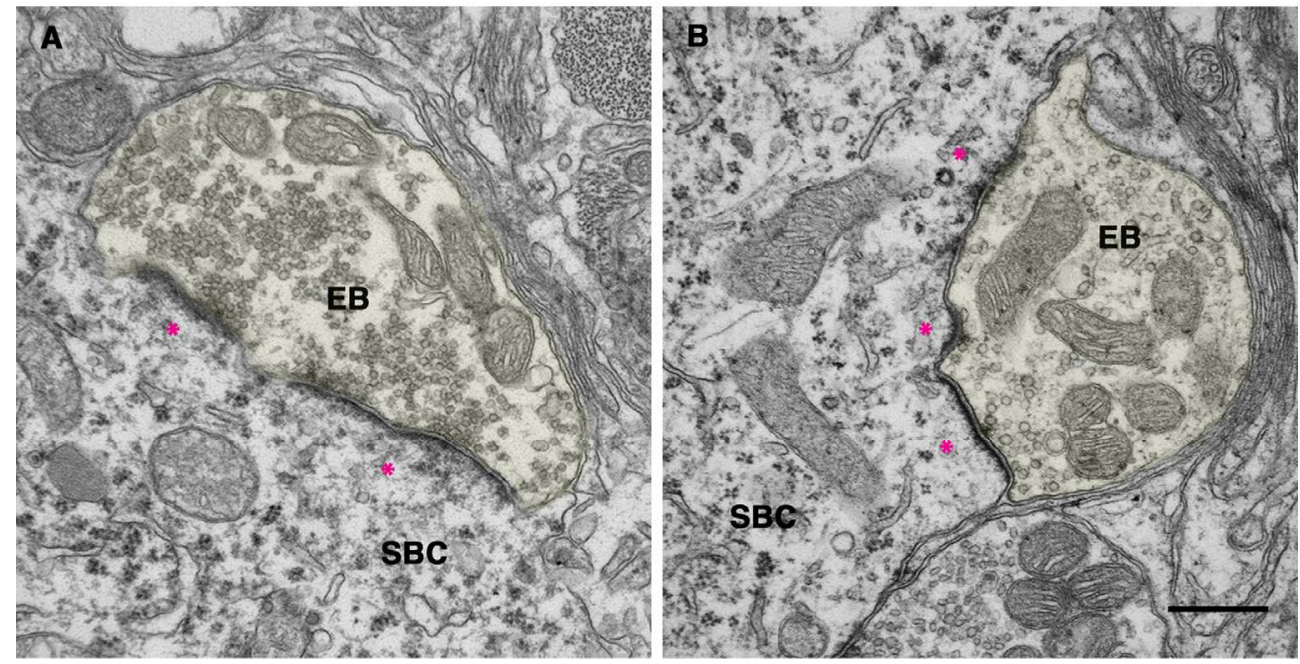

Fig. 8. Electron micrographs showing endbulbs of Held (EB) in deaf cats. Note the typical flat and elongated appearance of PSDs marked with asterisk. Scale bar $=0.5 \mu \mathrm{m}$. (Adapted from O'Neil, J.N.; Limb, C.J.; Baker, C.A. \& Ryugo, D.K. (2010). Bilateral effects of unilateral cochlear implantation in congenitally deaf cats. J Comp Neuro, Vol. 518, No. 12, pp. 2382-2404).

Congenital deafness does not restrict its effects to the auditory nerve and cochlear nucleus (Saada et al., 1996). Alterations in cell size and number, receptive field properties, and laminar organization are expressed at higher nuclei of the auditory system including the superior olivary complex (Schwartz \& Higa, 1982), inferior colliculus (Snyder et al., 2000), and auditory cortex (Klinke et al., 2001; Kral et al., 2001). Thus, alterations and plasticity at 
the endbulb synapse are reflections of a wider range of possible change throughout the central auditory system initiated by hearing loss and deafness.

\section{Critical period of development}

The concept of the critical period has been applied to explain biological phenomena that occur or are most severely affected over a brief period of time during development. Examples of such developmental events are exemplified by "imprinting" (Lorenz, 1935), cortical barrel plasticity (Weller \& Johnson, 1975), birdsong acquisition (Konishi, 1985), and functional maturation of auditory cortex (Chang \& Merzenich, 2003; Zhou et al., 2008). Reports that young children receiving cochlear implants gained far superior benefit compared to that of older children and adults also hinted strongly at a critical period (Gantz et al., 1994; Tyler \& Summerfield, 1996). In congenitally deaf cats, electrical stimulation was reported to recruit auditory cortical responses contingent upon its commencement before 6 months of age (Klinke et al., 2001; Kral et al., 2002). The structural foundation for these observations may be attributable to the fact that 3-month old cochlear implant recipients exhibited somewhat restored auditory nerve synapses, whereas 6-month old cochlear implant recipients did not ( $\mathrm{O}^{\prime} \mathrm{Neil}$ et al., 2010). The developmental period preceding puberty (cats reach puberty at six months of age) appears most favorable for implant-induced synaptic plasticity, and the restoration of endbulb synapses is hypothesized to have facilitated the proper delivery of afferent signals to the forebrain in a timely, coherent, and synchronized way.

\section{Synaptic plasticity: Implications for cochlear implants}

Synaptic strength and plasticity have been studied in other central synapses such as CA1 in the rat hippocampus where it was shown that the size of PSDs increases in response to pharmacological blockade of spike activity (e.g., Qin et al., 2001; Yasui et al., 2005). Quiescent synapses exhibited larger PSDs and increased numbers of synaptic vesicles that were accompanied by increases in synaptic strength. Consistent with this correlation, an increase in synaptic strength is seen in the AVCN of the congenitally deaf mouse when compared to that of normal hearing mice (Oleskevich \& Walmsley, 2002; Oleskevich et al., 2004). This increase in synaptic strength may be related to an increase in transmitter receptors that become distributed in the enlarged PSDs.

Several abnormalities have been demonstrated in the auditory system following deafness including reduced numbers of spiral ganglion neurons (Leake \& Hradek, 1988; Ryugo et al., 1998), abnormal synaptic structure (Ryugo et al., 1997), physiological alterations of auditory nerve responses in the cochlear nucleus (Oleskevich \& Walmsley, 2002; Wang \& Manis, 2006), and ectopic projections in the ascending pathways (Franklin et al., 2006). These changes undoubtedly affected synaptic transmission where degraded responses in the inferior colliculus (Vale \& Sanes, 2002; Vollmer et al., 2005) and auditory cortex (Kral et al., 2006) have been observed. Endbulbs are implicated in mediating the precise temporal processing of sound (Molnar \& Pfeiffer, 1968) and are known to transmit from auditory nerve to postsynaptic cell with a high degree of fidelity (Babalian et al., 2003). Detection and identification of some sounds are not nearly as demanding as the processing of temporal cues needed for sound localization, pattern recognition or speech comprehension. The introduction of synaptic jitter, delay, or failure by congenital deafness at the endbulb 
synapse appears to compromise such processing. If deafness-induced abnormalities go uncorrected, a cochlear implant may not be able to overcome the degraded signals, resulting in decreased benefit. The contribution of electrical activity to synaptic ultrastructure demonstrates that a cochlear implant can reverse some morphologic abnormalities in the auditory pathway when stimulation is started early.

\subsection{Restoration of the endbulb synapse}

Cochlear implants are electronic neural prostheses that are able to restore functional hearing to most individuals who are profoundly deaf or severely hard of hearing. Cochlear implants achieve their effects through bypassing the nonfunctioning auditory hair cell receptors of the inner ear and directly stimulating the auditory nerve (Rauschecker \& Shannon, 2002). Individuals who lose hearing after developing speech and congenitally deaf children who receive implants early in life are the best candidates for cochlear implants, although the level of benefit varies widely from one individual to the next. Young children under the age of 2 years who exhibit nonsyndromic sensorineural deafness are also excellent candidates (Waltzman et al., 1994, 1997). Because children who receive implants at progressively older ages tend to perform more poorly, it is hypothesized that uncorrected congenital deafness leads to irreversible abnormalities throughout the central auditory system.

The synaptic changes in auditory nerve endings associated with congenital deafness present an interesting test for thinking about sensory deprivation and brain plasticity. Restoration of auditory activity by unilateral electrical stimulation in deaf cats resulted in improvements in temporal processing at the level of the cortex (Klinke et al., 2001), the inferior colliculus (Vollmer et al., 2005) and the cochlear nucleus (Ryugo et al., 2005). We sought to determine whether synaptic abnormalities in the cochlear nucleus would represent the key to disrupting auditory processing throughout the central auditory system? Using miniaturized cochlear implants (Clarion II implants donated by Advanced Bionics Corporation) congenital deaf kittens were implanted at 3 and 6 months of age. The implants utilized a 6-electrode array. After a short period of recovery, each kitten was stimulated 7 hours a day, 5 days a week for 2-3 months. The device utilized a speech processor identical to that used with human patients (Kretzmer et al., 2004). During the period of stimulation animals learned to approach their food bowl in response to a specific "call" showing that the animals were processing signals of biological relevance. Synapse restoration was evident on the side of stimulation where the small size and dome-shaped curvature of the PSD returned (Ryugo et al., 2005, Figure 9) however, this was not observed in the 6-month late implanted group (O'Neil et al., 2010).

\subsection{Trans-synaptic changes in the auditory pathway}

Electrical stimulation of the auditory nerve via cochlear implantation restored many of the synaptic abnormalities associated with congenital deafness, including PSD size, distribution, and curvature, and synaptic vesicle density. The restored synapses, however, were not completely normal because intermembraneous cisternae that tend to flank release sites did not return (O'Neil et al., 2010). Moreover, electrically evoked ABRs differed from those in normal cats. Evoked peaks in the ABR waveform whose height and sharpness are indicative of synchronous ascending volleys, while more prominent in implanted cats compared to that of unstimulated congenitally deaf cats, were nonetheless delayed and flattened. These 
changes in ABR waveform suggest a loss of synchrony in the evoked responses, perhaps caused by an increase in transmission jitter or transmission failure. The ascending projections of SBCs are likely to sustain these abnormalities through the interaural time difference (ITD) circuitry.

\subsection{Trans-synaptic effects on spherical bushy cells}

Spike activity and neural transmission in spiral ganglion cells and their fibers appear essential for the normal development of cochlear nucleus neurons (Rubel \& Fritzsch, 2002). It follows that procedure's that increase neuronal survival should boost cochlear implant benefits such as improving speech comprehension. Studies that used ototoxic deafening of normal hearing cats have reported small but positive effects of electrical stimulation on cochlear nucleus cell size (Stakhovskaya et al., 2008), whereas others using similar methods show no effects (Coco et al., 2007). Our data show that electrical stimulation of auditory nerve fibers via cochlear implants had no effect on the size of the SBC neurons in this model of hereditary deafness. Because spiral ganglion neurons die at a faster rate with ototoxic treatments compared to hereditary deafness (Anniko, 1985), it may be that the ototoxic treatment not only damages auditory hair cell receptors but also spiral ganglion neurons and central neurons. Hereditary deafness obviously represents a different model from ototoxic deafness so it remains to be determined to what extent the results from the separate animal models are comparable.

\subsection{Changes in the Medial Superior Olive (MSO)}

Excitatory inputs to MSO neurons are segregated such that ipsilateral input innervates lateral dendrites and contralateral inputs innervate medial dendrites (Russell et al., 1995; Kapfer et al., 2002). These neurons function as a "coincidence detector" for processing ITDs (Carr et al., 2004). In addition, inhibitory inputs tend to be confined to the MSO cell bodies of mammals specialized for low frequency hearing (e.g., gerbil, cat, chinchilla). This topographical arrangement differs in MSO cells of mammals specialized for high frequency hearing (e.g., rat, opossum, bat, juvenile gerbil) where there is an equal excitatory-inhibitory synapse distribution on both cell somata and dendrites. Inhibitory input to the MSO arise from the medial and lateral nucleus of the trapezoid body (MNTB, LNTB, Grothe \& Sanes, 1993) and function to adjust the output signal of MSO neurons (Pecka et al., 2008). The spatial distribution of these excitatory and inhibitory inputs is sensitive to developmental abnormalities within the acoustic environment. Deafness causes a bilateral disruption in the spatially segregated inputs to the MSO principal neurons as seen in mammals with low frequency hearing. In congenitally deaf animals, inhibitory input at the cell somata is significantly less than what is observed in hearing controls (Kapfer et al., 2002; Tirko \& Ryugo, 2012).

This change in axosomatic inhibition was inferred by a loss of staining for gephyrin, an anchoring protein for the glycine receptor (Kapfer et al., 2002) and the migration of terminals containing flattened and pleomorphic synaptic vesicles (indicative of inhibitory synapses) away from the cell body. Excitatory inputs to the dendrites were severely shrunken. Two-to-three months of electrical stimulation via cochlear implantation of the congenitally deaf cat resulted in a partial restoration of the size of 
excitatory inputs to dendrites and a restoration of inhibitory input onto the cell somata (Tirko \& Ryugo, 2012).
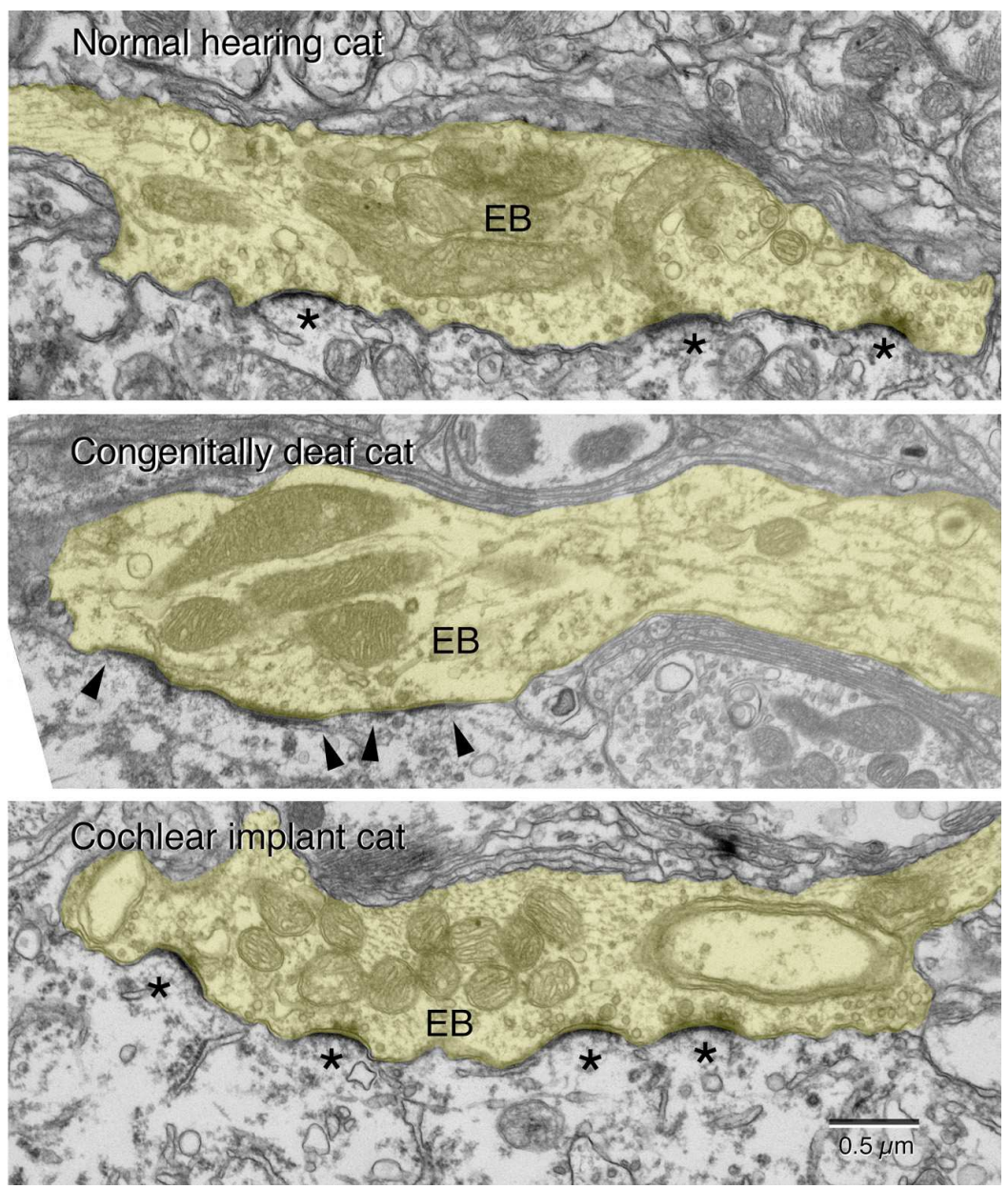

Fig. 9. Electron micrographs of endbulbs highlighted in yellow illustrating the restorative effect of activity on synapses. The endbulb of a congenitally deaf cat that received stimulation from a cochlear implant exhibits synapses with normal morphology. *Asterisks and arrowheads mark PSDs. (Adapted from Ryugo, D.K.; Kretzmer, E.A. \& Niparko, J.K. (2005). Restoration of auditory nerve synapses in cats by cochlear implants. Science, Vol. 310, No. 5753, pp. 1490-1492).

\subsection{Changes in the Lateral Superior Olive (LSO)}

The LSO is involved in interaural level differences (ILDs, Tollin, 2003). This circuit measures the difference in sound level or intensity between the two ears, since the ear further from the sound source receives a relatively softer sound due to the "shadow" 
effect of the head. This binaural nucleus also plays a central role in sound localization, specifically in the processing of high frequency sounds. ILDs are encoded by integrating both excitatory and inhibitory input. The LSO receives excitatory input from ipsilateral SBCs and inhibitory input from the MNTB that in turn receives input from the contralateral globular bushy cells (Kandler et al., 2009).

The MNTB provides glycinergic input to the LSO. Glycine is a major inhibitory transmitter providing synaptic inhibition in the LSO and other nuclei within the superior olivary complex (Caspary et al., 1994; Grothe \& Sanes, 1993). Inputs to the LSO are tonotopically organized similar to cochlear nuclei and are aligned so that a single neuron is excited and inhibited by the same sound frequency (Kandler et al., 2009).

Within the LSO, there is a remarkable degree of synaptic reorganization involving experience dependent plasticity that is important for normal auditory development (Kapfer et al., 2002; Kim \& Kandler, 2003). In gerbils, development of the MNTB-LSO pathway begins with synaptic pruning of MNTB axon terminals in the LSO and a decrease in the spread of LSO dendrites occurring after hearing onset. This pruning depends in large part on auditory experience (Kandler et al., 2009). The specific elimination and strengthening of GABA/glycinergic synapses is essential for the formation of a precise tonotopic map (Gillespie et al., 2005).

Deafness-associated plasticity at the synapse level has long been observed in the auditory midbrain (Caspary et al., 1999; Sato et al., 2000; Holt et al., 2005). These synaptic changes influences the balance of excitation and inhibition and are reflected in neuronal response profiles (Francis \& Manis, 2000; Syka et al., 2000; Syka \& Rybalko, 2000) that vary with respect to cell type. A decrease in excitatory transmission to the LSO produces alterations in synaptic and membrane properties affecting the maturation of synaptic strength. This effect may be a result of a change in total synaptic contacts, presynaptic release or postsynaptic cell response (Buras et al., 2006).

\subsection{Changes in the Inferior Colliculus (IC)}

The IC is a tonotopically organized nucleus of the midbrain receiving ascending auditory inputs from many sources including both cochlear nuclei, superior olivary complex, as well as descending inputs from the auditory cortex and superior colliculus. It is a large nucleus, bilaterally located and representing the main station through which most ascending projections must pass before reaching the auditory forebrain. A rudimentary tonotopic organization within the IC has been shown to exist in long-term deafened animals (Snyder et al., 1990; Shepherd et al., 1999). This organization is maintained in the absence of auditory input (i.e., deafness) implying that connections are in place prior to hearing onset (Young \& Rubel, 1986; Friauf \& Kandler, 1990). Acute deafness did not increase temporal dispersion in spike timing to electric pulse trains in the auditory nerve nor impair ITD sensitivity (Shephard \& Javel, 1997; Sly et al., 2007). Congenital deafness, however, did reduce ITD sensitivity in the responses of IC units. Single unit data in the IC showed that half as many neurons in the congenitally deaf cat showed ITD sensitivity to low pulse trains when compared to the acutely deafened animals. In neurons that showed ITD tuning, the tuning was found to be broader and more variable (Hancock et al., 2010). These findings reveal that ITD sensitivity is seriously affected by auditory deprivation and is consistent with what has been shown in humans with 
bilateral cochlear implants: these individuals perform better at distinguishing ILDs than ITDs. Collectively, the data imply that ITD discrimination is a highly demanding process and that even with near perfect synapse restoration, the task is sufficiently difficult that perhaps only complete restoration of synapses will enable the full return of function.

\subsection{Changes in auditory cortex}

Congenital deafness leads to functional and morphological changes in the auditory system from the cochlear nucleus, the first nuclei receiving auditory synaptic input to the auditory cortex (Kral et al., 2000, 2001). As clinical experience has shown, successful restoration of acoustic input to the auditory system depends on implantation age and sensitive periods in humans (Tyler et al., 1997; Busby \& Clark, 1999) as well as cats (Klinke et al., 2001; O'Neil et al., 2010). In congenitally deaf cats, the auditory cortex does not receive any sound evoked input. However, it does display some rudimentary cortical representation of cochleotopy (Hartmann et al., 1997) and ITDs (Tillein et al., 2010). Investigations on the functional deficits of the auditory cortices in adult deaf cats were conducted where synaptic currents in cortical layers were compared between electrically stimulated congenitally deaf and electrically stimulated normal hearing animals (Kral et al., 2000). Marked functional deficits were found in the auditory cortex of the congenitally deaf cat believed to result from degeneration of the corticocortical and thalamocortical projections. Auditory experience through implantation was found to be necessary for recruitment and maturation of the auditory cortex, and such experience expanded the functional area of auditory cortex over that of animals who did not receive meaningful stimulation (Klinke et al., 2001).

\section{Plasticity and binaural pathways}

The ILD is the auditory cue used for localizing high-frequency sounds, whereas, ITD is the dominant auditory cue for localizing low-frequency sounds. These cues make up the binaural pathways important for sound-source localization. The endbulb synapse has been implicated in the ITD pathway that processes the precise timing features of sound that is crucial for binaural hearing. SBCs send projections from the AVCN to the superior olivary complex (Cant \& Casseday, 1986). These projections terminate onto ipsilateral neurons of the LSO and bilaterally upon bipolar neurons of the MSO. In the MSO, inputs from the right cochlear nucleus terminate on the dendrites facing the right, whereas inputs from the left cochlear nucleus terminate on the dendrites facing left. The MSO is a key nucleus that processes synaptic input from both ears (Figure 10).

ITDs are crucial for localizing sounds on the horizontal plane. The ITD pathway utilizes the difference in arrival of a sound at the two ears to place a sound source. The general concept for this binaural sensitivity is the coincidence detection model where neurons would only respond when binaural excitatory inputs converged simultaneously (Jeffress, 1948). In this model, an array of MSO neurons receive systematically arranged inputs, each with a delay line such that it would only respond if a sound source were in a particular position off the midline. Some neurons would respond when the sound was directly in front of the animal, whereas others would respond when the sound moved away from the midline.

A delay line would compensate for a progressive shift in time of arrival at the two ears. The system is sensitive to differences in the range of tens of microseconds, so it is clear that precision in synaptic transmission is required (Grothe, 2000). 


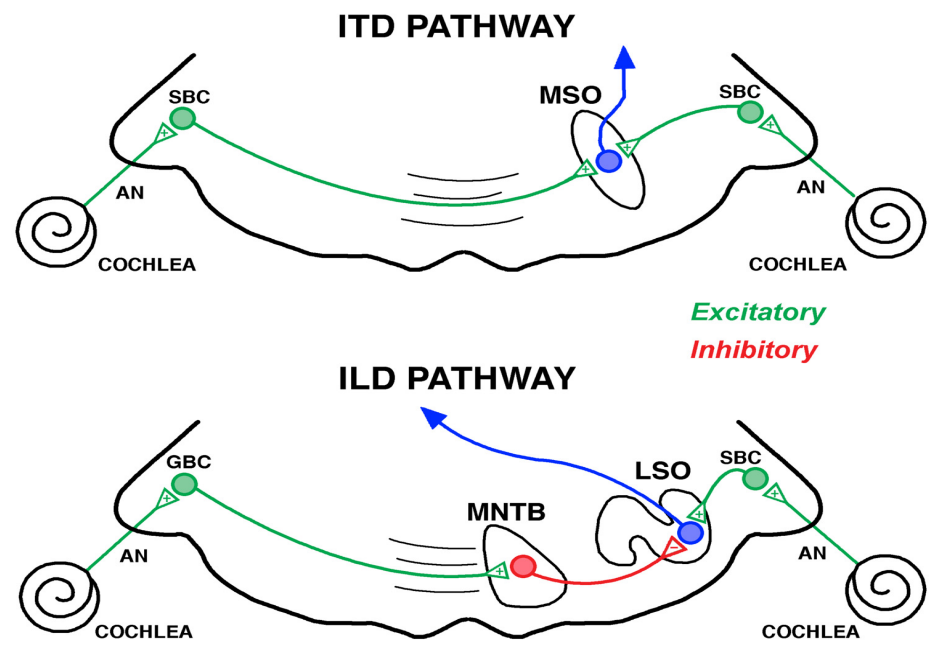

Fig. 10. Duplicity Theory Pathway (Adapted from Tollin, D.J. (2003). The lateral superior olive: a functional role in sound source localization. Neuroscientist, Vol. 9, No. 2, pp. 127-143 and O'Neil, J.N.; Connelly, C.J.; Limb, C.J. \& Ryugo, D.K. (2011). Synaptic morphology and the influence of auditory experience. Hear Res, Vol. 279, No. 1-2, pp. 118-30).

The endbulb, therefore, is not only important for processing important timing cues for sound localization but also for time-varying cues in speech such as voice onset, stressed syllables, gaps, and amplitude modulation (Blackburn \& Sachs, 1990). The point of this discussion is to emphasize that endbulbs and the timing of neural activity are linked and highly important to the proper processing and perception of sound.

\section{Auditory function}

Auditory experience has been shown to influence the maturation of the central auditory system throughout development. Auditory nerve activity in the form of spike discharges is necessary for the initial formation of precise synaptic structure, tonotopic organization, and proper distribution of terminals in the ascending auditory pathway. Abnormalities in organization result in a corruption of signal processing within the brain that ultimately impairs auditory perception. Structural changes occur in the brainstem and have been described in the congenitally deaf white cat model. The re-establishment of activity through electrical stimulation results in a remarkable recovery of the involved synapses and circuit organization. (O’Neil et al., 2011; Tirko \& Ryugo, 2012).

Implants have allowed individuals with profound deafness, in particular children, to acquire speech understanding, language and social skills. Some benefits of binaural hearing can be accomplished with bilateral cochlear implants. Individuals affected with bilateral hearing loss implanted with sequentially cochlear implants benefit by having better speech understanding, especially in noise, and better sound localization. It allows the first ear that is implanted to preserve some of the benefits of binaural hearing somewhat avoiding the effects of auditory deprivation on the unimplanted ear. Auditory function can be somewhat 
restored by use of a cochlear implant depending on age at implant and upon how much auditory activity was available prior to implant.

\section{Conclusion}

Considerable progress has been made as a result of intensive cochlear implant research and development over the last forty years by adapting electronic technology for use in a physiological system. In doing so, the "world of hearing" have been opened to thousands of individuals in many countries. Even though the benefits of cochlear implants are many there is still progress to be made in addressing the extensive difficulties implant users have in localization of sound sources and the ability to enjoy music.

\section{Acknowledgments}

The authors gratefully acknowledge the support from NIH grants DC000232, DC005211, DC0023 and grants from the Office of Science and Medical Research, NSW, NMHRC grant \#1009482, and the Garnett Passe and Rodney Williams Memorial Foundation.

\section{References}

Anniko, M. (1985). Principles in cochlear toxicity. Arch Toxicol, Suppl, Vol. 8, pp. 221-239

Babalian, A.L.; Ryugo, D.K. \& Rouiller, E.M. (2003). Discharge properties of identified cochlear neurons and auditory nerve fibers in response to repetitive electrical stimulation of the auditory nerve. Exp Brain Res, Vol. 153, No. 4, pp. 452-460

Baker, C.A.; Montey, K.L.; Pongstaporn, T. \& Ryugo, D.K. (2010). Postnatal development of the endbulb of Held in congenitally deaf cats. Front Neuroanat, Vol. 4, pp. 1-14

Blackburn, C.C. \& Sachs, M.B. (1990). The representations of the steady-state vowel sound /e/ in the discharge patterns of cat anteroventral cochlear nucleus neurons. J Neurophysiol, Vol. 63, No. 5, pp. 1191-1212

Buras, E.D.; Holt, A.G.; Griffith, R.D.; Asako, M. \& Altschuler, R.A. (2006). Changes in glycine immunoreactivity in the rat superior olivary complex following deafness. $J$ Comp Neurol, Vol. 494, No. 1, pp. 179-189

Burwen, S.J. \& Satir, B.H. (1977). Plasma membrane folds on the mast cell surface and their relationship to secretory activity. J Cell Biol, Vol. 74, No. 3, pp. 690-697

Busby, P.A. \& Clark, G.M. (1999). Gap detection by early-deafened cochlear-implant subjects. J Acoust Soc Am, Vol. 105, No. 3, pp. 1841-1852

Cant, N.B. \& Casseday, J.H. (1986) projections from the anteroventral cochlear nucleus to the lateral and medial superior olivary nuclei. J Comp Neurol, 247 No. 4, pp. 457-476

Carr, C.E. \& Koppl, C. (2004). Coding interaural time differences at low best frequencies in the barn owl. J Physiol, Vol. 98, No. 1-3 pp. 99-112

Caspary, D.M.; Backoff, P.M.; Finlayson, P.G. \& Palombi, P.S. (1994). Inhibitory inputs modulate discharge rate within frequency receptive fields of anteroventral cochlear nucleus neurons. J Neurophysiol, Vol. 72, No. 5, pp. 2124-2133

Caspary, D.M.; Holder, T.M.; Hughes, L.F.; Milbrandt, J.C.; McKerman R.M. \& Naritoku, D.K. (1999). Age-related changes in GABA (A) receptor subunit composition and function in rat auditory system. Neuroscience, Vol. 93, No. 1, pp. 307-312 
Chang, E.F., \& Merzenich, M.M. (2003). Environmental noise retards auditory cortical development. Science, Vol. 300, No. 5618, pp. 498-502

Coco, A.; Epp, S.B.; Fallon, J.B.; Xu, J.; Millard, R.E. \& Shepherd, R.K. (2007). Does cochlear implantation and electrical stimulation affect residual hair cells and spiral ganglion neurons? Hear Res, Vol. 225, No. 1-2, pp. 60-70

Djourno, A.; Eyries, C. \& Vallancien, B. (1957). Premiers essays d'excitation électrique du nerf auditif chez l'homme, par microappareils incus a demeure. Bull Natl Acad Med, 141, pp. $481-483$

Doyle, J.H.; Doyle, J.B. Jr. \& Turnbull F.M. Jr. (1964). Electrical stimulation of eight cranial nerve. Arch Otololaryngol, Vol. 80, pp. 388-391

Eisen, M.D. (2009) The history of cochlear implants. In: Cochlear implants: principles and practices (2nd ed), J.K. Niparko, (Ed.), pp. 89-94, Lippincott Williams \& Wilkins, Philadelphia, PA

Fay, R.R. (1988). Hearing in vertebrates: a psychophysics databook, Hill-Fay Associates, Winnetka, IL

Francis, H.W. \& Manis, P.B. (2000). Effects of deafferentation on the electrophysiology of ventral cochlear nucleus neurons. Hear Res, Vol. 149, No. 1-2, pp. 91-105

Franklin, S.R.; Bruno-Bechtold, J.K. \& Henkel, C.K. (2006). Unilateral cochlear ablation before hearing onset disrupts the maintenance of dorsal nucleus of the lateral lemniscus projection patterns in the rat inferior colliculus. Neuroscience, Vol. 143, No.1, pp. 105-115

Friauf, E. \& Kandler, K. (1990). Auditory projections to the inferior colliculus of the rat are present by birth. Neurosci Lett, Vol. 120, No. 1, pp. 58-61

Gantz, B.J.; Tyler, R.S.; Woodworth, G.G.; Tye-Murray, N. \& Fryauf-Bertschy, H., (1994). Results of multichannel cochlear implants in congenital and acquired prelingual deafness in children: five-year follow-up. Am J Otol, Vol. 15, Suppl 2, pp. 1-7

Gersuni, G.V. \& Volokhov, A.A. (1936). On the electrical excitability of the auditory organ: On the effect of alternating currents on the normal auditory apparatus. $J$ Exp Psychol, Vol. 19, pp. 370-382

Gillespie, D.C.; Kim, G. \& Kandler, K. (2005). Inhibitory synapses in the developing auditory system are glutamatergic. Nat Neurosci, Vol. 8, No. 3, pp. 332-338

Grothe, B. (2000). The evolution of temporal processing in the medial superior olive, an auditory brainstem structure. Prog Neurobiol, Vol. 61, pp. 581-610

Grothe, B. \& Sanes, D.H. (1993). Bilateral inhibition by glycinergic afferents in the medial superior olive. J Neurophysiol, Vol. 69, No.4, pp. 1192-1196

Gulley, R.L.; Landis, D.M. \& Reese, T.S. (1978). Internal organization of membranes at endbulbs of Held in the anteroventral cochlear nucleus. J Comp Neurol, Vol. 180, No. 4, pp. 707-741

Hancock, K.; Noel, V.; Ryugo, D.K. \& Delgutte, B. (2010). Neural coding of ITD with bilateral cochlear implants: Effects of congenital deafness. J Neurosci, Vol. 30, No. 42, pp. 14068-14079

Hartmann, R.; Shepherd, R.K.; Heid, S. \& Klinke, R. (1997). Response of the primary auditory cortex to electrical stimulation of the auditory nerve in the congenitally deaf white cat. Hear Res, Vol. 112, No. 1-2, pp. 115-133

Held, H. (1893). Die centrale Gehorleitung. Arch. Anat. Physiol. Anat. Abt. 17, pp. 201-248

Holt, A.G.; Asako, M.; Lomax, C.A.; MacDonald, J.W.; Tong, L.; Lomax, M.I. \& Altschuler, R.A. (2005). Deafness-related plasticity in the inferior colliculus: gene expression 
profiling following removal of peripheral activity. J Neurochem, Vol. 93, No.5, pp. 1069-1086

House, W.F. (1976). Cochlear implants. Ann Otol Rhinol Laryngol, Vol. 85, s27(3pt2), pp. 1-93

Jeffress, L.A. (1948). A place theory of sound localization. J Comp Physiol Psychol, Vol. 41, No. 1, pp. 35-39

Jerison, J.H. (1973). Evolution of the Brain and Intelligence, New York, Academic Press

Kandler, K. (2004). Activity-dependent organization of inhibitory circuits: lessons from the auditory system. Curr Opin Neurobiol, Vol. 14, No. 1, pp. 96-104

Kandler, K.; Clause, A. \& Noh, J. (2009). Tonotopic reorganization of developing auditory brainstem circuits. Nat Neurosci, Vol. 12, No. 6, pp. 711-717

Kapfer, C.; Seidl, A.H.; Schweizer, H. \& Grothe, B. (2002). Experience-dependent refinement of inhibitory inputs to auditory coincidence-detector neurons. Nat Neurosci, Vol. 5, No. 3, pp. 247-253

Kiang, N.Y.S.; Watanabe, T.; Thomas, E.C. \& Clark, L.F. (1965). Discharge Patterns of Single Fibers in the Cat's Auditory Nerve, M.I.T. Press, Cambridge, MA

Kim, G. \& Kandler, K. (2003). Elimination and strengthening of glycinergic/GABAergic connections during tonotopic map formation. Nat Neurosci, Vol. 6, No. 3, pp. 282-290

Klinke, R.; Hartmann, R.; Heid, S.; Tillein, J. \& Kral, A. (2001). Plastic changes in the auditory cortex of congenitally deaf cats following cochlear implantation. Audiol Neurootol, Vol. 6, No. 4, pp. 203-206

Koerber, K.C., Pfeiffer, R.R., Warr, W.B. \& Kiang, N.Y. (1966). Spontaneous spike discharges from single units in the cochlear nucleus after destruction of the cochlea. Exp Neurol, Vol. 16, No. 2, pp. 119-130

Kral, A.; Hartmann, R.; Tillein, J.; Heid, S. \& Klinke, R. (2000). Congenital auditory deprivation reduces synaptic activity within the auditory cortex in a layer-specific manner. Cereb Cortex, Vol. 10, No. 7, pp. 714-726

Kral, A.; Hartmann, R.; Tillein, J.; Heid, S. \& Klinke, R. (2001). Delayed maturation and sensitive periods in the auditory cortex. Audiol Neurootol, Vol. 6, No. 6, pp. 346- 362

Kral, A.; Hartmann, R.; Tillein, J.; Heid, S. \& Klinke, R. (2002). Hearing after congenital deafness: central auditory plasticity and sensory deprivation. Cereb Cortex, Vol. 12, No. 8, pp. 797-807

Kral, A.; Tillein, J.; Heid, S.; Klinke, R. \& Hartmann, R. (2006). Cochlear implants: cortical plasticity in congenital deprivation. Prog Brain Res, Vol. 157, pp. 283-313

Kretzmer, E.A.; Meltzer, N.E.; Haenggeli, C.A. \& Ryugo, D.K. (2004). An animal model for cochlear implants. Arch Otolaryngol Head Neck Surg, Vol. 130, No. 5, pp. 499-508

Konishi, M. (1985). Birdsong: From behavior to neuron. Ann Rev Neurosci, Vol. 8, pp. 125- 170

Leake, P.A. \& Hradek, G.T. (1988). Cochlear pathology of long term neomycin induced deafness in cats. Hear Res, Vol. 33, No. 1, pp. 11-33

Leake, P.A.; Hradek, G.T.; Chair, L. \& Snyder, R.L. (2006). Neonatal deafness results in degrade topographic specificity of auditory nerve projections to the cochlear nucleus in cats. J Comp Neurol, Vol. 497, No.1, pp. 13-31

Lee, D.J.; Cahill, H.B. \& Ryugo, D.K. (2003). Effects of congenital deafness in the cochlear nuclei of Shaker-2 mice: an ultrastructural analysis of synapse morphology in the endbulbs of Held. J Neurocytol, Vol. 32, No. 3, pp. 229-243

Lenn, N.J. \& Reese, T.S. (1966). The fine structure of nerve endings in the nucleus of the trapezoid body and the ventral cochlear nucleus. Am J Anat, Vol. 118, No. 2, pp. 375-389 
Limb, C.J. \& Ryugo, D.K. (2000). Development of primary axosomatic endings in the anteroventral cochlear nucleus of mice. J Assoc Res Otolaryngol, Vol. 1, No. 2, pp. 103-119

Lorente de Nó, R. (1981). The Primary Acoustic Nuclei. Raven Press, New York

Lorenz, K. (1935). Der Kumpan in der Umwelt des Vogels. Der Artgenosse als auslosendes Moment sozialer Verhaltensweisen. J fur Ornithologie, 83, pp. 137-413

Manis, P.B. \& Marx, S.O. (1991). Outward currents in isolated central cochlear nucleus neurons. J Neurosci, Vol. 11, No. 9, pp. 2865-2880

Michelson, R.P. (1971). The results of electrical stimulation of the cochlea in human sensory deafness. Ann Otol Rhinol Laryngol, Vol. 80, No. 6, pp. 914-919

Molnar, C.E. \& Pfeiffer R.R. (1968). Interpretation of spontaneous discharge patterns of neurons in the cochlear nucleus. Proc IEEE, Vol. 56, No. 6, pp. 993-1004

Nicol, M.J. \& Walmsley, B. (2002). Ultrastructural basis of synaptic transmission between endbulbs of held and bushy cells in the rat cochlear nucleus. J Physiol, Vol. 539(Pt 3), pp. 713-723

Niparko, J.K.; Lingua C. \& Carpenter R.M. (2009). Assessment of Candidacy for Cochlear Implant Implantation, In: Cochlear Implants: principles and practices, (2nd ed), John K. Niparko (Ed.), pp. 137-146, Lippincott Williams \& Wilkins, Philadephia, PA

Nordeen, K.W.; Killackey, H.P. \& Kitzes, L.M. (1983). Ascending projections to the inferior colliculus following unilateral cochlear ablation in the adult gerbil, Meriones unguiculatus. J Comp Neurol, Vol. 214, No. 2, pp. 131-143

Oleskevich, S. \& Walmsley, B. (2002). Synaptiic transmission in the auditory brainstem of normal and congenitally deaf mice. J Physiol, 540(Pt 2), pp. 447-455

Oleskevich, S.; Youssoufian, M. \& Walmsley, B. (2004). Presynaptic plasticity at two giant auditory synapses in normal and deaf mice. J Physiol, Vol. 560(Pt 3), pp. 709-719

O'Neil, J.N.; Limb, C.J.; Baker, C.A. \& Ryugo, D.K. (2010). Bilateral effects of unilateral cochlear implantation in congenitally deaf cats. J Comp Neurol, Vol. 518, No. 12, pp. 2382-2404

O'Neil, J.N.; Connelly, C.J.; Limb, C.J. \& Ryugo, D.K. (2011). Synaptic morphology and the influence of auditory experience. Hear Res, Vol. 279, No. 1-2,pp. 118-130

Parks, T.N.; Rubel, E.W.; Popper, A.N. \& Fay, R.R. (Eds), (2004). Plasticity of the Auditory System, Springer, New York

Pecka, M.; Brand, A.; Behrend, O. \& Grothe, B. (2008). Interaural time difference processing in the mammalian medial superior olive: the role of glycinergic inhibition. $J$ Neurosci, Vol. 28, No. 27, pp. 6914-6925

Qin, L.; Marrs, G.S.; McKim, R. \& Dailey, M. (2001). Hippocampal mossy fibers induce assembly and clustering of PSD95 containing postsynaptic densities independent of glutamate receptor activation. J Comp Neurol, Vol. 440, No. 3, pp. 284-298

Rauschecker, J.P. \& Shannon, R.V. (2002). Sending sound to the brain. Science Vol. 295, No. 5557, pp. 1025-1029

Rees, S.; Guldner, F.H. \& Aitkin, L. (1985). Activity dependent plasticity of postsynaptic density structure in the ventral cochlear nucleus of the rat. Brain Res, Vol. 325, No. (1-2) pp. 370-374

Robbins, A.M. (2006). Language development in children with cochlear implants. In: Cochlear Implants, Waltzman, S.B., Roland Jr., J.R. (Eds.), pp. 153-166, Thieme Medical Publishers, New York 
Rubel, E.W. \& Fritzsch, B. (2002). Auditory system: primary auditory neurons and their targets. Annu Rev Neurosci, 25, pp. 51-101

Rubel, E. W. \& Parks, T. N. (1988). Organization and development of the avian brain-stem auditory system. In: Auditory Function: The Neurobiological Basis of Hearing, Edelman, G. M., Gall, W. E., \& Cowan, W. M. (Eds.), pp. 3-9, Wiley, NewYork

Russell, F.A. \& Moore, D.R. (1995). Afferent reorganization within the superior olivary complex of the gerbil: development and induction by neonatal, unilateral cochlear removal. J Comp Neurol, Vol. 352, No. 4, pp. 607-625

Ryugo, D.K.; Baker, C.A.; Montey, K.L.; Chang, L.Y.; Coco, A.; Fallon, J.B. \& Shepherd, R.K. (2010). Synaptic plasticity after chemical deafening and electrical stimulation of the auditory nerve in cats. J Comp Neurol, Vol. 518, No. 7, pp. 1046-1063

Ryugo, D.K. \& Fekete, D. M. (1982). Morphology of primary axosomatic endings in the anteroventral cochlear nucleus of the cat: a study of the endbulbs of Held. J Comp Neurol, Vol. 210, No. 3, pp. 239-257

Ryugo, D.K.; Kretzmer, E.A. \& Niparko, J.K. (2005). Restoration of auditory nerve synapses in cats by cochlear implants. Science, Vol. 310, No. 5753, pp. 1490-1492

Ryugo, D.K. \& Parks, T.N. (2003). Primary innervation of the avian and mammalian cochlear nucleus. Brain Res Bull, Vol. 60, No. 5-6, pp. 435-456

Ryugo, D.K. \& Spirou G.A. (2009). Auditory System: Giant Synaptic Terminals, Endbulbs and Calyces. In: New Encyclopedia of Neuroscience, Vol.1, Squire L.R. (Ed.), pp. 759770, Academic Press, Oxford

Ryugo, D.K.; Pongstaporn, T.; Huchton, D.M. \& Niparko, J.K. (1997). Ultrastructural analysis of primary endings in deaf white cats: morphologic alterations in endbulbs of Held. J Comp Neurol, Vol. 385, No. 2, pp. 230-244

Ryugo, D.K.; Rosenbaum, B.T.; Kim, P.J.; Niparko, J.K. \& Saada, A.A. (1998). Single unit recordings in the auditory nerve of congenitally deaf white cats: morphological correlates in the cochlea and cochlear nucleus. J Comp Neurol, Vol. 397, No. 4, pp. 532-548

Ryugo, D.K. \& Sento, S. (1991). Synaptic connections of the auditory nerve in cats: relationship between endbulbs of held and spherical bushy cells. J Comp Neurol, Vol. 305, No. 1, pp. 35-48

Ryugo, D.K.; Wu, M.M. \& Pongstaporn, T. (1996). Activity-related features of synapse morphology: a study of endbulbs of Held. J Comp Neurol, Vol. 365, No. 1, pp. 141- 158

Saada, A.A.; Niparko, J.K. \& Ryugo, D.K. (1996). Morphological changes in the cochlear nucleus of congenitally deaf white cats. Brain Res, Vol. 736, No. 1-2, pp. 315-328

Sato, K.; Shiraishi, S.; Nakagawa, H.; Kuriyama, H. \& Altschuler, R.A. (2000). Diversity and plasticity in amino acid receptor subunits in the rat auditory brain stem. Hear Res, Vol. 147, No. 1-2, pp. 137-144

Scheibe, A. (1882). A case of deaf-mutism, with auditory atrophy and anomalies of development in the membraneous labyrinth of both ears. Arch Otolaryngol, Vol. 21, pp. 12-22

Schwartz, I.R. \& Higa, J.F. (1982). Correlated studies of the ear and brainstem in the deaf white cat: changes in the spiral ganglion and the medial superior olivary nucleus. Acta Otolaryngol, Vol. 93, No. 1-2, pp. 9-18 
Sento, S. \& Ryugo, D.K. (1989). Endbulbs of Held and spherical bushy cells in cats: Morphological correlates with physiological properties. J Comp Neuro, Vol. 280, No. 4, pp. 553-562

Shepherd, R.K. \& Javel, E. (1997). Electrical stimulation of the auditory nerve. I. Correlation of physiological responses with cochlear status. Hear Res, Vol. 108, No. 1-2, pp. 112-144

Shepherd, R.K. \& Javel, E. (1999). Electrical stimulation of the auditory nerve: II. Effect of stimulus waveshape on single fibre response properties. Hear Res, 130, No. 1-2, pp. 171-188

Shepherd, R.K.; Meltzer, N.E.; Fallon, J.B. \& Ryugo, D.K. (2006). Consequences of deafness and electrical stimulation on the peripheral and central auditory system. In: Cochlear Implants. Waltzman, S.B., Roland, J.T., (Eds.), pp. 25-39, Thieme Medical Publishers, New York

Simons, L.A.; Dunlop, C.W.; Webster, W.R. \& Aitkin, L.M. (1966). Acoustic habituation in cats as a function of stimulus rate and the role of temporal conditioning of the middle ear musles. Electroencephalogr Clin Neurophysiol, Vol. 20, No. 5, pp. 485-493

Sly, D.J.; Heffer, L.F.; White, M.W.; Shepherd, R.K.; Birch, M.G.; Minter, R.L.; Nelson, N.E.; Wise, A.K. \& O'Leary, S.J. (2007). Deafness alters auditory nerve fibre responses to cochlear implant stimulation. Eur J Neurosci, Vol. 26, No. 2, pp. 510-522

Snyder, R.L.; Rebscher, S.J.; Cao, K.L.; Leake, P.A. \& Kelly, K. (1990). Chronic intracochlear electrical stimulation in the neonatally deafened cat. I: Expansion of central representation. Hear Res, Vol. 50, No. 1-2, pp. 7-33

Snyder, R.L.; Vollmer, M.; Moore, C.M.; Rebscher, S.J.; Leake, P.A. \& Beitel, R.E. (2000). Responses of inferior colliculus neurons to amplitude-modulated intracochlear electrical pulses in deaf cats. J Neurophysiol, Vol. 84, No. 1, pp. 166-183

Stakhovskaya, O.; Hradek, G.T.; Snyder, R.L. \& Leake, P.A. (2008). Effects of age at onset of deafness and electrical stimulation on the developing cochlear nucleus in cats. Hear Res, Vol. 243, No. 1-2, pp. 69-77

Stevens, S.S. \& Jones, R.C. (1939). The mechanism of hearing by electrical stimulation. J Acoust Soc Am, Vol. 10, pp. 261-269

Suga, F. \& Hattler, K.W. (1970). Physiological and histopathological correlates of hereditary deafness in animals. Laryngoscope, Vol. 80, No. 1, pp. 81-104

Syka, J.; Popelar, J.; Kvasnak, E. \& Astl, J. (2000). Response properties of neurons in the central nucleus and external and dorsal cortices of the inferior colliculus in guinea pig. Exp Brain Res, Vol. 133, No. 2, pp. 254-266

Syka, J. \& Rybalko, N. (2000). Threshold shifts and enhancement of cortical evoked responses after noise exposure in rats. Hear Res, Vol. 139, No. 1-2, pp. 59-68

Tillein, J.; Hubka, P.; Syed, E.; Hartmann, R.; Engel, A.K. \& Kral, A. (2010). Cortical representation of interaural time difference in congenital deafness. Cereb Cortex, Vol. 20, No. 2, pp. 492-506

Tirko, N.N. \& Ryugo, D.K. (2012). Synaptic plasticity in the medial superior olive of hearing, deaf, and cochlear-implanted cats. J Comp Neurol, (Epub ahead of print)

Tollin, D.J. (2003). The lateral superior olive: a functional role in sound source localization. Neuroscientist, Vol. 9, No. 2, pp. 127-143

Tyler, R.S.; Fryauf-Bertschy, H.; Gantz, B.J.; Kelsay, D.M. \& Woodworth, G.G. (1997). Speech perception in prelingually implanted children after four years. Adv Otorhinolaryngol, Vol. 52, pp. 187-192 
Tyler, R.S. \& Summerfield, A.Q. (1996). Cochlear implantation: relationships with research on auditory deprivation and acclimatization. Ear Hear, Vol. 17, No. 3, pp. 38S-50S

Vale, C. \& Sanes, D.H. (2002). The effect of bilateral deafness on excitatory and inhibitory synaptic strength in the inferior colliculus. Eur J Neurosci, Vol. 16, No. 12, pp. 2394-2404

Vollmer, M.; Leake, P.A.; Beitel, R.E.; Rebscher, S.J. \& Snyder, R.L. (2005). Degradation of temporal resolution in the auditory midbrain after prolonged deafness is reversed by electrical stimulation of the cochlea. J Neurophysiol, Vol. 93, No. 6, pp. 3339-3355

Waltzmann, S.B.; Cohen, N.L. \& Shapiro, W.H. (1991). Effects of chronic electrical stimulation on patients using cochlear prosthesis. Otolaryngol Head Neck Surg, Vol. 105, No. 6, pp. 797-801

Waltzman, S.B.; Cohen, N.L.; Gomolin, R.H.; Green, J.E.; Shapiro, W.H.; Hoffman, R.A. \& Roland, J.T., Jr. (1997). Open-set speech perception in congenitally deaf children using cochlear implants. Am J Otol, Vol. 18, No. 3, pp. 342-349

Waltzman, S.B.; Cohen, N.L.; Gomolin, R.H.; Shapiro, W.H.; Ozdamar, S.R. \& Hoffman, R.A. (1994). Long-term results of early cochlear implantation in congenitally and prelingually deafened children. Am J Otol, Vol. 15 Suppl 2, pp. 9-13

Waltzman, S.B. \& Roland, J.T. Jr. (2005). Cochlear implantation in children younger than 12 months. Pediatrics, Vol. 116, No. 4, pp. 487-493

Wang, Y. \& Manis, P.B. (2006). Temporal coding by cochlear nucleus bushy cells in DBA/2J mice with early onset hearing loss. J Assoc Res Otolaryngol, Vol. 7, No. 4, pp. 412-424

Weller, W.L. \& Johnson, J.L. (1975). Barrels in cerebral cortex by receptor disruption in newborn, but not in five-day-old mice (Cricetidoe and Muridae). Brain Res, Vol. 83, pp. 504-508

Wever, E.G. \& Bray, C.W. (1930). Auditory nerve impulses. Science, Vol. 71, No. 1834, pp. 215

Yasui, T.; Fujisawa, S.; Tsukamoto, M.; Matsuki, N. \& Ikegaya, Y. (2005). Dynamic synapses as archives of synaptic history: state-dependent redistribution of synaptic efficacy in the rat hippocampal CA1. J Physiol, Vol. 566(Pt 1), pp. 143-160

Young, S.R. \& Rubel, E.W. (1986). Embryogenesis of arborization pattern and topography of individual axons in N. laminaris of the chicken brain stem. J Comp Neuro, Vol. 254, No. 4, pp. 425-459

Zhou, X.; Nagarajan, N.; Mossop, B.J. \& Merzenich, M.M. (2008). Influences of unmodulated acoustic inputs on functional maturation and critical-period plasticity of the primary auditory cortex. Neuroscience, Vol. 154, No. 1, pp. 390-396

http://www.nidcd.nih.gov/health/statistics/Pages/quick.aspx

http://www.nidcd.nih.gov/health/hearing/pages/coch.aspx 


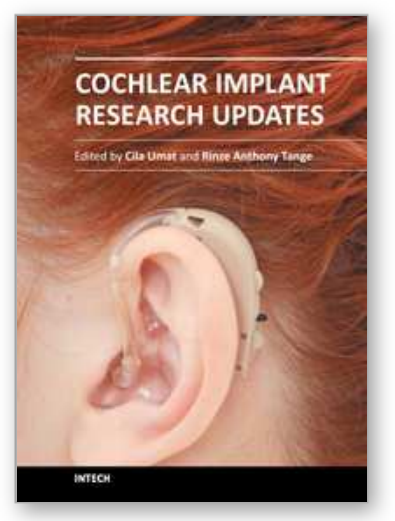

\author{
Cochlear Implant Research Updates \\ Edited by Dr. Cila Umat
}

ISBN 978-953-51-0582-4

Hard cover, 232 pages

Publisher InTech

Published online 27, April, 2012

Published in print edition April, 2012

For many years or decades, cochlear implants have been an exciting research area covering multiple disciplines which include surgery, engineering, audiology, speech language pathology, education and psychology, among others. Through these research studies, we have started to learn or have better understanding on various aspects of cochlear implant surgery and what follows after the surgery, the implant technology and other related aspects of cochlear implantation. Some are much better than the others but nevertheless, many are yet to be learnt. This book is intended to fill up some gaps in cochlear implant research studies. The compilation of the studies cover a fairly wide range of topics including surgical issues, some basic auditory research, and work to improve the speech or sound processing strategies, some ethical issues in language development and cochlear implantation in cases with auditory neuropathy spectrum disorder. The book is meant for postgraduate students, researchers and clinicians in the field to get some updates in their respective areas.

\title{
How to reference
}

In order to correctly reference this scholarly work, feel free to copy and paste the following:

Jahn N. O'Neil and David K. Ryugo (2012). Cochlear Implantation, Synaptic Plasticity and Auditory Function, Cochlear Implant Research Updates, Dr. Cila Umat (Ed.), ISBN: 978-953-51-0582-4, InTech, Available from: http://www.intechopen.com/books/cochlear-implant-research-updates/cochlear-implantation-synaptic-plasticityand-auditory-function

\section{INTECH}

open science | open minds

\section{InTech Europe}

University Campus STeP Ri

Slavka Krautzeka 83/A

51000 Rijeka, Croatia

Phone: +385 (51) 770447

Fax: +385 (51) 686166

www.intechopen.com

\section{InTech China}

Unit 405, Office Block, Hotel Equatorial Shanghai

No.65, Yan An Road (West), Shanghai, 200040, China

中国上海市延安西路65号上海国际贵都大饭店办公楼 405 单元

Phone: +86-21-62489820

Fax: $+86-21-62489821$ 
(C) 2012 The Author(s). Licensee IntechOpen. This is an open access article distributed under the terms of the Creative Commons Attribution 3.0 License, which permits unrestricted use, distribution, and reproduction in any medium, provided the original work is properly cited. 